\title{
LeVel of Creative Thinking EFFect Through Multiple Solution TASK TyPe Problem-SOLVING ON LEARNING OUTCOMES
}

\author{
Muhammad Kris Yuan Hidayatulloh ${ }^{1)}$, Supari Muslim ${ }^{2)}$, Erina Rahmadyanti ${ }^{3)}$, Euis Ismayati ${ }^{4)}$ \\ Nita Kusumawati ${ }^{5)}$ \\ ${ }^{1)}$ Universitas Negeri Surabaya, Surabaya, Indonesia \\ E-mail: muhammadhidayatulloh10@mhs.unesa.ac.id \\ ${ }^{2)}$ Universitas Negeri Surabaya, Surabaya, Indonesia \\ E-mail: supari@unesa.ac.id \\ ${ }^{3)}$ Universitas Negeri Surabaya, Surabaya, Indonesia \\ E-mail: erinarahmadyanti@unesa.ac.id \\ ${ }^{4)}$ Universitas Negeri Surabaya, Surabaya, Indonesia \\ E-mail: euisheru@gmail.com \\ ${ }^{5)}$ Universitas Negeri Surabaya, Surabaya, Indonesia \\ E-mail: nitakusumawati99@gmail.com
}

\begin{abstract}
This study aims to: (1) analyze the level of creative thinking possessed by each class XI students of Building Drawing Technique (BDT); and (2) analyze the influence of the level of thinking on the learning outcomes of the cognitive, affective, and psychomotor domains. This type of research is correlational research through a quantitative approach method. The population in this study were all students in building expertise competencies at SMK Negeri 1 Nganjuk which included Geomatics and BDT. The sample used in this study was XI BDT class students. The instrument used in analyzing the level of creative thinking (LCT) is a problem-solving test sheet of the type of multiple solution tasks. The data analysis technique uses a linear regression test. The results of the study concluded that: (1) there were as many as 4 students included in the category of LCT 4 (very creative), there were 12 students included in the category of LCT 3 (creative), there are 11 students included in the category 2 LCT (quite creative), there are no students included in the category of LCT 1 (less creative), and there are as many as 11 students who included in the category of LCT 0 (not creative); (2) there is a significant influence between the level of creative thinking on the cognitive and psychomotor learning outcomes; and (3) there is a very significant influence between the level of creative thinking on the affective learning outcomes of class XI BDT students.
\end{abstract}

Keywords: Level of Creative Thinking; Simple Situation Map; Multiple Solution Task; Problem-Solving

\section{INTRODUCTION}

Vocational high school (VHS) is a level of education equivalent to high school (HS), but this level of education is more focused on the world of work and alumni from this level of education are expected to be able to compete in employment. The Building Drawing Techniques Department (BDT) is one of the majors where students are educated to be competent in drawing a building construction. The BDT Expertise Program aims to prepare graduates to become middle-level workers within the scope of BDT expertise (architectural design) who can work independently 
professionally and can develop themselves in their fields of expertise (Anonymous, 2019).

Thomas (2005) states that creativity is a concept where theoretical assumptions are tested, questioned, and changed to think of something extraordinary or through new methods, and also to think of unique solutions to some problems. Whereas Howard (2002) views that creativity is a theoretical activity that produces a new facet of some problems and no product boundary is seen by its function so that decision making or general solutions will become new solutions. According to Colangelo \& Davis (2011), creativity in learning can be improved through (1) motivation; (2) awareness of knowledge; (3) attitude and practice; (4) effective learning; and (5) include students in activities that require a type of creative thinking. Therefore, Lubis views that creativity is a decisive prerequisite for individuals in improving the quality of life (Nuraeni, 2008). One's creativity is also very much needed in the world of work based on the Maine Department of Labor's Career Center (Hidayatulloh \& Suparji, 2015) which stated that some of the competencies expected in the world of work today are selfesteem, motivation for achievement (motivation to achieve), mastery of some basic skills, technical knowledge, thinking skills, which include submission of problems (problemposing), problem-solving, decision making, analytical thinking, and creative thinking. In line with the demands of life in the 21 st century that a person must have 4 skills, namely critical thinking, creativity and innovation, collaboration, and communication (Trilling \& Fadel, 2009).

Given the importance of the ability to think creatively, the world of education needs to pay close attention to the development of creativity possessed by students. Explicitly, creative thinking ability is loaded into one of the principles of curriculum development for junior/MTs students and high school/MA/SMK by the Departemen Pendidikan Nasional. (2006). Teachers as the main facilitators in education are expected to be able to design learning methods and learning approaches in such a way that they have the potential to develop the creative thinking abilities that students have so that they influence the learning outcomes and their careers in the future.

The study was conducted to analyze the level of creative thinking of students in solving the problem of measuring the situation map based on the problem type of multiple solution tasks using the material to measure the situation map area. Material for measuring the area map of the situation was chosen because it allowed students to solve problems using a variety of solutions following the characteristics of the problem type multiple solution tasks. During this time the teacher has given much attention to learning. Seen from a variety of strategies, learning methods and learning models and even learning media used by teachers to invite students to be more active in learning and improve student learning outcomes, but the teacher's attention is only focused on student learning outcomes in understanding problems and solving problems. Based on the explanation above can be asked the statement that there is an effect of LCT on learning outcomes in the cognitive, affective, and psychomotor domains.

The creative thinking ability possessed by students can be known through a task that can identify these abilities. Silver (1997) states that the assessment of creative thinking skills of children and adults can use "The Torrance Test of Creative Thinking (TTCT)". The TTCT creativity assessment is based on three key components which include fluency, flexibility, and novelty. Students' creative thinking ability based on TTCT assessment can be measured by giving Multiple Solution Task (MST). Multiple Solution Task is a task that explicitly asks students to find more than one way to solve a given problem (Leikin, 2009). Leikin Roza and Anat Levav-Waynberg (Bingolbali, 2011) assert that "Solving problems in multiple ways contributes to the development of students' creativity and critical thinking". Problem-solving in different ways contributes to creativity and critical thinking skills for students. The creativity that is owned by everyone is an existing potential that can be measured and developed. This shows the existence of a different level of creative thinking (LCT). Siswono (2008) divided LCT into five levels, namely LCT 4 (very creative), LCT 3 (creative), LCT 2 (quite creative), LCT 1 (less creative), and LCT 0 (not creative) based on three creative thinking indicators.

\section{Methodology}

This research is a type of correlational research. The population in this study were all students of building engineering study at SMK Negeri 1 Nganjuk. The sampling method used was random sampling and selected class XI BDT as a sample in the study. Hypothesis testing is done by linear regression test.

\section{A. Research Instrument}

The instrument used in the study to analyze the level of creative thinking of class XI BDT students in the material for measuring the situation map was done through solving multiple solution task types at SMK Negeri 1 Nganjuk which consisted of LCT test sheets, cognitive learning outcomes tests, and observation sheets effective learning outcomes, and psychomotor domains.

\section{1) LCT Test Sheet}

The problem of multiple solution tasks consists of one item using the situation map measurement material. This study uses material Measurement of the situation map in determining the extent of the basic framework because the material is one of the calculation material that has the appropriate characteristics for multiple solution tasks. Students are asked to work on the problem in the form of a situation map that has been presented in the form of scale images. Questions are given to students to solve them in various ways they know both from school lessons, reading books, or the internet, or self-development. 


\section{2) Learning Outcomes Test}

Learning Outcomes Test in this study used multiplechoice forms that have been validated through item analysis. Learning outcomes instruments used must be valid, so they can know the accuracy and accuracy in performing their functions as a measure of learning outcomes.

\section{3) Observation Sheet}

The observation sheet in this study is to observe the learning outcomes of affective domains and psychomotor domains. Observations were made by three observers, including the spiritual attitudes and social attitudes of students on effective learning outcomes, and observations about performance on psychomotor domains.

\section{B. LCT Data Analysis Techniques}

The LCT test results were analyzed based on fluency, flexibility, and novelty components, then analyzed based on the level of creative thinking. The steps in the analysis of written test data are as follows: (1) compiling an expert solution space; (2) compiling an expert solution space; and (3) analysis of the level of creative thinking.

Step 1: Arrange an expert solution space

In this study, the material used is the measurement of the area of the situation map, where the way of solving the problems given are as follows: (1) right-angled coordinates method; (2) triangle circuit method; (3) grid method; (3) polar method; (4) lane method; (5) perpendicular coordinate method; and (6) digital methods/AutoCad.

Step 2: Analyze individual solution space

After obtaining the results of a written test of multiple solution tasks from all students, then analyzed to obtain the percentage of novelty in a class and arranged into scoring creativity as shown in Table 1.

TABLE I

SCORING SCHEME IN MULTIPLE SOLUTION TASK

\begin{tabular}{|c|c|c|}
\hline $\begin{array}{l}\text { Fluenc } \\
\text { y (Fa) }\end{array}$ & $\begin{array}{l}\text { Flexibility } \\
\text { (Fl) }\end{array}$ & $\begin{array}{l}\text { Novelty } \\
\text { (Ba) }\end{array}$ \\
\hline \multirow{10}{*}{1} & $F l i=10$ & $B a i=10$ \\
\hline & For the first solution & when $\mathrm{P}<15 \%$ or \\
\hline & $F l i=10$ & unconventional \\
\hline & For the different & solution \\
\hline & solution from the first & $B a i=1$ \\
\hline & solution & When $15 \% \leq \mathrm{P}<$ \\
\hline & $F l i=1$ & $40 \%$ or partly \\
\hline & $\begin{array}{l}\text { For the similar solution } \\
\text { from the previous } \\
\text { solution }\end{array}$ & $\begin{array}{l}\text { unconventional } \\
\text { solution }\end{array}$ \\
\hline & $F l i=0.1$ & $B a i=0.1$ \\
\hline & $\begin{array}{l}\text { For the same solution } \\
\text { from the previous } \\
\text { solution }\end{array}$ & $\begin{array}{l}\text { When } \mathrm{P} \geq 40 \% \text { or } \\
\text { conventional solution }\end{array}$ \\
\hline $\mathrm{Fa}=\mathrm{n}$ & $\mathrm{Fl}=\sum \mathrm{FLi}$ & $\mathrm{Ba}=\sum^{\mathrm{n}} \mathrm{Bai}$ \\
\hline & $i=1$ & $\sum_{0=1}^{2}$ \\
\hline
\end{tabular}

(Source: adapted from Leikin, 2009)
Information :

- Students are said to be fluent in solving problems if the student can produce at least three correct solutions (Fa score $\geq 3$ )

- Students are said to be flexible in solving problems if the student can produce at least two ways of solving which are both different and correct ( $\mathrm{Fl}$ score $\geq 20$ ).

- Students are said to be new in solving problems if the student can produce at least one unique way of solving or less than $15 \%$ of the answers of all students who work in this way (Ba score $\geq 10$ ).

Step 3: Analysis of the level of creative thinking

From the results of the analysis of three components of creative thinking, then the level of students' creative thinking was identified (Siswono, 2008) as shown in Table II.

TABLE II

FORMULATION OF SISWONO'S LCT (2008)

\begin{tabular}{cccc}
\hline \multirow{2}{*}{ LCT } & \multicolumn{3}{c}{ Components of Creative Thinking } \\
\cline { 2 - 4 } & $\begin{array}{c}\text { fluency } \\
(\text { Fa } \geq \mathbf{3})\end{array}$ & $\begin{array}{c}\text { Flexibility } \\
(\text { Fi } \geq \mathbf{2 0})\end{array}$ & $\begin{array}{c}\text { Novelty } \\
(\mathbf{B a} \geq \mathbf{1 0})\end{array}$ \\
\hline \multirow{2}{*}{ LCT 4 } & $\sqrt{ }$ & $\sqrt{ }$ & $\sqrt{ }$ \\
LCT 3 & - & - & $\sqrt{ }$ \\
& $\sqrt{ }$ & $\sqrt{ }$ & $\sqrt{ }$ \\
LCT 2 & $\sqrt{ }$ & - & - \\
LCT 1 & - & $\sqrt{ }$ & - \\
LCT 0 & $-\sqrt{ }$ & - & - \\
\hline
\end{tabular}

Information :

LCT : level of creative thinking

$\sqrt{ } \quad$ : eligible

- $\quad$ : not eligible

\section{Analysis of Learning Outcomes}

Analysis of student learning outcomes data aims to describe the completeness of learning outcomes that have been achieved by students. Analysis of cognitive learning outcomes was obtained from the score assessment items and the observation scores for the affective and psychomotor domains of learning outcomes. Students are declared complete if they can achieve a learning outcome score of $\geq$ 75 , both for cognitive, learning outcomes, effective domains, and psychomotor domains.

\section{Data Analysis Techniques of Respondents}

After knowing LCT for each student, the data analysis technique to analyze the effect of LCT on learning outcomes was carried out as follows.

\section{1) Test Requirements}

\section{- Distribution Normality Test}

The distribution normality test aims to find out whether the data obtained is normally distributed or not. Data tested for distribution normality included scores on cognitive, affective, psychomotor learning outcomes, and LCT scores. 
The distribution normality test was analyzed by the Smirnov Collimogorous test through statistical software.

\section{- Linearity Test}

The linearity test is used to find out whether the form of the equation produced is linear or not. Data tested by linearity included scores on cognitive, affective, and psychomotor domains of learning on LCT scores. The linearity test was analyzed by comparing the mean through statistical software.

\section{- Heteroscedasticity Test}

The heteroscedasticity test is used to determine the occurrence of variance inequalities from residuals from one observation to another. The data tested heteroscedasticity included residual scores on cognitive, affective, and psychomotor learning outcomes on LCT scores. Heteroscedasticity tests were analyzed by regression coefficient test through statistical software.

\section{2) Hypothesis testing}

Hypothesis testing is used to analyze the effect of LCT on student learning outcomes. Statistical tests were performed using linear regression through statistical software. (1) there is a positive and very significant effect of LCT on cognitive domain learning outcomes, (2) there is a positive and very significant effect of LCT on affective domain learning outcomes, and (3) there is a positive and very significant effect of LCT on psychomotor domain learning outcomes.

\section{RESULTS AND DISCUSSIONS}

\section{A. Results}

Retrieval of data in this study was carried out at SMK Negeri 1 Nganjuk class XI BDT. The results of the study include MST test scores and cognitive, affective, and psychomotor domains.

\section{1) Multiple Solution Task Results Data}

The individual solution space (answers produced by students) on problem-solving questions using the material measuring area maps, produces several ways as shown in Table III.

TABLE III

Number Of Students Using SPeCIFIC SeTtLement Methods

\begin{tabular}{lcr}
\hline \multirow{2}{*}{ Solutions Code } & \multicolumn{2}{c}{ Data } \\
\cline { 2 - 3 } & $\begin{array}{c}\text { Number of } \\
\text { students }\end{array}$ & Percentage \\
\hline right angled coordinates & 20 & $55.56 \%$ \\
method (S1) & 14 & $38.89 \%$ \\
Triangle circuit method (S2) & 28 & $77.78 \%$ \\
Grid method (S3) & 0 & $00.00 \%$ \\
Polar method (S4) & 10 & $27.78 \%$ \\
Lane method (S5) & 0 & $00.00 \%$ \\
Perpendicular coordinate & & $11.11 \%$ \\
method (S6) & 4 & \\
Digital methods / AutoCad & & \\
(S7) &
\end{tabular}

In giving a score on the individual solution space produced by students, a scoring guide for each component is summarized in scoring creativity. Determination of scores for each component of creative thinking in each method of completion refers to the scoring scheme of Leikin (2009) found in Table I. The results of scoring creativity were formulated as shown in Table IV.

TABLE IV

SCORING CREATIVITY OBTAINED FROM MST

\begin{tabular}{cccc}
\hline \multirow{2}{*}{ Solution Code } & \multicolumn{3}{c}{ Creative Thinking Components } \\
\cline { 2 - 4 } & Fa & Fl & Ba \\
\hline S1 & 1 & 10 & 1 \\
S2 & 1 & 10 & 0,1 \\
S3 & 1 & 10 & 0,1 \\
S4 & - & - & - \\
S5 & 1 & 10 & 1 \\
S6 & - & - & - \\
S7 & 1 & 10 & 10 \\
\hline
\end{tabular}

After getting each student's fluency, flexibility, and novelty score based on the creativity scoring above, students are grouped or identified based on LCT using predetermined indicators. The results of the identification of LCT students of class XI BDT of SMK Negeri 1 Nganjuk who take the test write the multiple solution tasks as shown in Table V.

TABLE V

RECAPITULATION OF LCT RESULTS FOR CLASS XI BDT STUDENTS IN RESOLVING PROBLEMS

\begin{tabular}{rcccccl}
\hline \multirow{2}{*}{ No } & \multirow{2}{*}{ Subject } & \multicolumn{2}{c}{ Indicators of } & LCT & Score & LCT \\
\cline { 3 - 5 } & Fa & Fl & Ba & LCT & \\
\hline 01 & S1 & - & $\sqrt{ }$ & - & 46.18 & LCT 2 \\
02 & S2 & - & $\sqrt{ }$ & - & 46.18 & LCT 2 \\
03 & S3 & - & - & - & 28.11 & LCT 0 \\
04 & S4 & - & - & - & 4.02 & LCT 0 \\
05 & S5 & $\sqrt{ }$ & $\sqrt{ }$ & - & 68.27 & LCT 3 \\
06 & S6 & - & - & - & 2.01 & LCT 0 \\
07 & S7 & $\sqrt{ }$ & $\sqrt{ }$ & - & 68.27 & LCT 3 \\
08 & S8 & - & $\sqrt{ }$ & - & 46.18 & LCT 2 \\
09 & S9 & - & $\sqrt{ }$ & $\sqrt{ }$ & 66.27 & LCT 4 \\
10 & S10 & $\sqrt{ }$ & $\sqrt{ }$ & - & 68.27 & LCT 3 \\
11 & S11 & - & $\sqrt{ }$ & - & 44.18 & LCT 2 \\
12 & S12 & - & - & - & 0.00 & LCT 0 \\
13 & S13 & - & $\sqrt{ }$ & - & 44.18 & LCT 2 \\
14 & S14 & - & - & - & 22.09 & LCT 0 \\
15 & S15 & - & - & - & 22.09 & LCT 0 \\
16 & S16 & - & $\sqrt{ }$ & - & 44.18 & LCT 2 \\
17 & S17 & - & - & - & 24.10 & LCT 0 \\
18 & S18 & - & $\sqrt{ }$ & - & 48.19 & LCT 2 \\
19 & S19 & - & - & - & 22.09 & LCT 0 \\
20 & S20 & - & - & - & 2.01 & LCT 0 \\
21 & S21 & - & $\sqrt{ }$ & - & 44.18 & LCT 2 \\
22 & S22 & $\sqrt{ }$ & $\sqrt{ }$ & - & 68.27 & LCT 3 \\
23 & S23 & - & - & - & 22.09 & LCT 0 \\
24 & S24 & - & $\sqrt{ }$ & - & 46.18 & LCT 2 \\
25 & S25 & $\sqrt{ }$ & $\sqrt{ }$ & - & 50.20 & LCT 3 \\
26 & S26 & $\sqrt{ }$ & $\sqrt{ }$ & - & 50.20 & LCT 3 \\
27 & S27 & $\sqrt{ }$ & $\sqrt{ }$ & - & 74.30 & LCT 3 \\
28 & S28 & $\sqrt{ }$ & $\sqrt{ }$ & - & 50.20 & LCT 3 \\
& & & & & &
\end{tabular}




\begin{tabular}{|c|c|c|c|c|c|c|}
\hline \multirow{2}{*}{ No } & \multirow{2}{*}{ Subject } & \multicolumn{3}{|c|}{ Indicators of LCT } & \multirow{2}{*}{$\begin{array}{l}\text { Score } \\
\text { LCT }\end{array}$} & \multirow{2}{*}{ LCT } \\
\hline & & $\mathbf{F a}$ & Fl & $\mathbf{B a}$ & & \\
\hline 29 & S29 & $\sqrt{ }$ & $\sqrt{ }$ & - & 50.20 & LCT 3 \\
\hline 30 & S30 & $\sqrt{ }$ & $\sqrt{ }$ & - & 50.20 & LCT 3 \\
\hline 31 & S31 & - & $\sqrt{ }$ & $\sqrt{ }$ & 64.26 & LCT 4 \\
\hline 32 & S32 & - & - & - & 28.11 & LCT 0 \\
\hline 33 & S33 & - & $\sqrt{ }$ & - & 46.18 & LCT 2 \\
\hline 34 & S34 & - & $\sqrt{ }$ & - & 44.18 & LCT 2 \\
\hline 35 & S35 & $\sqrt{ }$ & - & $\sqrt{ }$ & 92.37 & LCT 3 \\
\hline 36 & S36 & $\sqrt{ }$ & - & $\sqrt{ }$ & 86.35 & LCT 3 \\
\hline & Total & 12 & 23 & 4 & & \\
\hline
\end{tabular}

Based on Table $\mathrm{V}$, it can be seen that the creative thinking ability of class X BDT students of SMK Negeri 1 Nganjuk consists of: (1) there are as many as 12 students (33.33\%) who can demonstrate fluency; (2) there are 23 students $(63.89 \%)$ who can show flexibility; and (3) as many as 4 students $(11.11 \%)$ who were able to show novelty in solving the problem of the type of multiple solution tasks using the material measurement of the situation map. Percentage of creative thinking level of class XI BDT students of SMK Negeri 1 Nganjuk, as shown in Fig. 1.

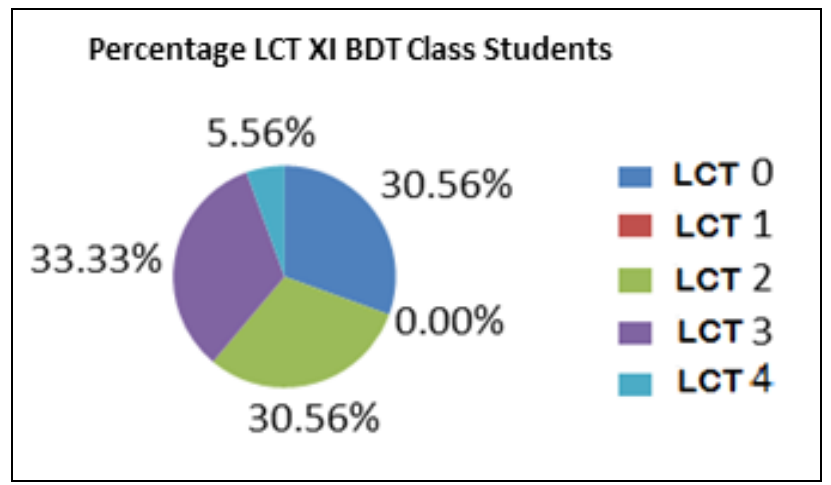

Fig. 1 Percentage LCT Diagram of Class XI BDT Students

Based on Table V and Fig. 1, it can be seen that LCT class XI BDT of SMK Negeri 1 Nganjuk in solving problems in the type of multiple solution tasks with material measuring the situation map based on fulfilled creative thinking components can be grouped as follows: (1) number of students those in LCT 3 (creative) dominated more than 12 students $(33.33 \%)$; (2) there are 11 students $(30.56 \%)$ in LCT 0 (not creative) and LCT 2 (quite creative); and (3) there are 4 students $(5.56 \%)$ in LCT 4 (very creative).

\section{2) Student Learning Outcomes}

Data Scores of cognitive, affective, and psychomotor learning outcomes were analyzed through statistical software, and results were obtained as shown in Table VI.

TABLE VI

Statistical Data SCORE OF StUdent LEARNing OUTCOMES

\begin{tabular}{lccc}
\hline \multirow{2}{*}{ Parameter } & \multicolumn{3}{c}{ The results of the Domain Study } \\
\cline { 2 - 4 } & Cognitive & Affective & Psychomotor \\
\hline Mean & 82.36 & 85.68 & 79.40 \\
Std, Error of Mean & 1.48 & 0.30 & 0.68 \\
Median & 80.00 & 85.67 & 78.80 \\
\hline
\end{tabular}

\begin{tabular}{lccc}
\hline \multirow{2}{*}{\multicolumn{1}{c}{ Parameter }} & \multicolumn{3}{c}{ The results of the Domain Study } \\
\cline { 2 - 4 } & Cognitive & Affective & Psychomotor \\
\hline Mode & 75.00 & 84.33 & 77.87 \\
Std, Deviation & 8.90 & 1.82 & 4.070 \\
Std, Deviation & 8.90 & 1.82 & 4.070 \\
Variance & 79.27 & 3.33 & 16.56 \\
Skewness & 0.29 & 0.06 & 0.20 \\
Std, Error of & 0.39 & 0.39 & 0.39 \\
Skewness & -0.61 & -0.96 & -0.93 \\
Kurtosis & 0.77 & 0.77 & 0.77 \\
Std, Error of & 35.00 & 6.50 & 15.45 \\
Kurtosis & 65.00 & 82.50 & 71.67 \\
Range & 100.00 & 89.00 & 87.12 \\
Minimum & \multicolumn{2}{c}{} \\
Maximum & \multicolumn{3}{c}{} \\
\hline
\end{tabular}

Histograms along with the normal curves of score data on cognitive, affective, and psychomotor learning outcomes are presented in Fig. 2.

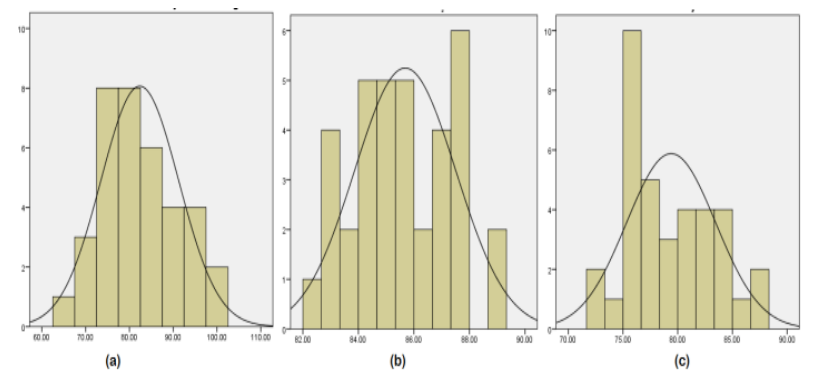

Fig. 2 Histograms and Normal Curves Score Learning Outcomes of the Territory: (a) Cognitive; (b) Affective; and (c) Psychomotor

\section{3) Test Requirements}

- Distribution Normality Test

The normality test was carried out on the scores of cognitive, affective, psychomotor, and student LCT scores. The test results are presented in Table VII.

TABLE VII

NORMALITY TEST RESULTS

\begin{tabular}{|c|c|c|c|c|c|}
\hline \multicolumn{2}{|c|}{ Parameters } & $\begin{array}{l}\text { Cognitive } \\
\text { learning } \\
\text { outcomes }\end{array}$ & $\begin{array}{l}\text { Affective } \\
\text { learning } \\
\text { outcomes }\end{array}$ & $\begin{array}{l}\text { psychomotor } \\
\text { learning } \\
\text { outcomes }\end{array}$ & $\begin{array}{l}\text { Score } \\
\text { LCT }\end{array}$ \\
\hline $\mathrm{N}$ & & 36 & 36 & 36 & 36 \\
\hline \multirow{2}{*}{$\begin{array}{l}\text { Normal } \\
\text { Parameters }\end{array}$} & Mean & 82.361 & 85.684 & 79.395 & 44.00 \\
\hline & $\begin{array}{l}\text { Std. } \\
\text { Deviation }\end{array}$ & 8.903 & 1.823 & 4.069 & 22.946 \\
\hline \multirow{3}{*}{$\begin{array}{l}\text { Most } \\
\text { Extreme } \\
\text { Differences }\end{array}$} & Absolute & 0.160 & 0.104 & 0.129 & 0.197 \\
\hline & Positive & 0.160 & 0.104 & 0.129 & 0.144 \\
\hline & Negative & -0.093 & -0.075 & -0.086 & -0.197 \\
\hline \multicolumn{2}{|c|}{ Kolmogorov-Smirnov Z } & 0.961 & 0.627 & 0.772 & 1.184 \\
\hline \multicolumn{2}{|c|}{ Asymp. Sig. (2-tailed) } & 0.314 & 0.827 & 0.590 & 0.121 \\
\hline
\end{tabular}

The output of the Kolmogorov Smirnov test results through statistical software shows $>0.05$ so that it can be concluded that the scores of cognitive, affective, psychomotor, and LCT learning outcomes are normally distributed. 
- Linearity Test

Data tested by linearity included scores on cognitive, affective, and psychomotor domains of learning on LCT scores. The test results are presented in Table VIII.

TABLE VIII

LINEARITY TEST RESULTS

\begin{tabular}{|c|c|c|c|c|c|c|c|}
\hline \multicolumn{3}{|c|}{ Learning Outcomes Score } & \multirow{2}{*}{\begin{tabular}{|l|}
$\begin{array}{c}\text { Sum of } \\
\text { Squares }\end{array}$ \\
1913.056
\end{tabular}} & \multirow{2}{*}{$\frac{\text { df }}{15}$} & \multirow{2}{*}{$\begin{array}{l}\begin{array}{l}\text { Mean } \\
\text { Square }\end{array} \\
127.537\end{array}$} & \multirow{2}{*}{$\begin{array}{c}\text { F } \\
2.962\end{array}$} & \multirow{2}{*}{$\begin{array}{l}\text { Sig. } \\
0.012\end{array}$} \\
\hline Cognitive & Between & (Combined) & & & & & \\
\hline $\begin{array}{l}\text { domain * } \\
\text { LCT }\end{array}$ & Groups & $\begin{array}{l}\text { Linearity } \\
\text { Deviation }\end{array}$ & 976.035 & 1 & 976.035 & 22.666 & 0.000 \\
\hline \multirow[t]{2}{*}{ Score } & & $\begin{array}{l}\text { from } \\
\text { Linearity }\end{array}$ & 937.020 & 14 & 66.930 & 1.554 & 0.179 \\
\hline & \multicolumn{2}{|c|}{ Within Groups } & $\begin{array}{r}861.250 \\
2774.306\end{array}$ & $\begin{array}{l}20 \\
35\end{array}$ & 43.063 & & \\
\hline \multirow{4}{*}{$\begin{array}{l}\text { Affective } \\
\text { domain * } \\
\text { LCT } \\
\text { Score }\end{array}$} & Between & (Combined) & 45.184 & 15 & 3.012 & 0.846 & 0.624 \\
\hline & Groups & $\begin{array}{l}\text { Linearity } \\
\text { Deviation }\end{array}$ & 13.687 & 1 & 13.687 & 3.843 & 0.064 \\
\hline & & $\begin{array}{l}\text { from } \\
\text { Linearity }\end{array}$ & 31.497 & 14 & 2.250 & 0.632 & 0.809 \\
\hline & \multicolumn{2}{|c|}{$\begin{array}{l}\text { Within Groups } \\
\text { Total }\end{array}$} & $\begin{array}{r}71.237 \\
116.421\end{array}$ & $\begin{array}{l}20 \\
35\end{array}$ & 3.562 & & \\
\hline \multirow{5}{*}{$\begin{array}{l}\text { Psychom } \\
\text { otor } \\
\text { domain * } \\
\text { LCT } \\
\text { Score }\end{array}$} & $\begin{array}{l}\text { Between } \\
\text { Groups }\end{array}$ & (Combined) & 395.034 & 15 & 26.336 & 2.852 & 0.015 \\
\hline & & $\begin{array}{l}\text { Linearity } \\
\text { Deviation }\end{array}$ & 111.205 & 1 & 111.205 & 12.045 & 0.002 \\
\hline & & $\begin{array}{l}\text { from } \\
\text { Linearity }\end{array}$ & 283.829 & 14 & 20.273 & 2.196 & 0.053 \\
\hline & \multirow{2}{*}{\multicolumn{2}{|c|}{$\begin{array}{l}\text { Within Groups } \\
\text { Total }\end{array}$}} & 184.651 & 20 & 9.233 & & \\
\hline & & & 579.685 & 35 & & & \\
\hline
\end{tabular}

The output of the statistical software shows $>0.05$ so that it can be concluded that there is a significant linear relationship between LCT with learning outcomes in the cognitive, affective, and psychomotor domains.

\section{- Heteroscedasticity Test}

Tested for residual heteroscedasticity from scores on cognitive, affective, and psychomotor domains of learning on LCT scores. The test results are presented in Table IX.

TABLE IX

HETEROSCEDASTICITY TEST RESULTS

\begin{tabular}{llrrrrr}
\hline & & \multicolumn{2}{c}{$\begin{array}{c}\text { Unstandardized } \\
\text { Coefficients }\end{array}$} & $\begin{array}{c}\text { Standardized } \\
\text { Coefficients }\end{array}$ & & \multirow{2}{*}{ t } \\
\cline { 3 - 5 } & & B & $\begin{array}{c}\text { Std. } \\
\text { Error }\end{array}$ & Beta & & \\
\hline 1 & (Constant) & 4.586 & 1.652 & & 2.776 & 0.009 \\
& LCT Score & 0.021 & 0.033 & 0.107 & .626 & 0.535 \\
\hline
\end{tabular}

The output of statistical software shows $>0.05$ so that it can be concluded that the independent variable does not occur heteroscedasticity towards the dependent variable.

\section{4) Hypothesis testing}

The entire prerequisite test has been carried out to linear regression analysis. The hypothesis testing is used to determine whether the answer is one of the problem statements is accepted or rejected. The statistical hypothesis test used is linear regression. The effect of LCT on cognitive domain learning outcomes is presented in Table X.

Based on Table 10, the linear regression equation is as follows: $\mathrm{R}=72,233+0,230 \mathrm{X}$. If student LCT does not change/constant, the cognitive learning outcomes are worth 72,2333 . The significance shows $0,000<0,01$ so it can be concluded that there is a positive and very significant effect of LCT on cognitive domain learning outcomes. The effect of LCT on affective learning outcomes analyzed through statistical software is presented in Table X.

TABLE X

LCT LINEAR REGRESSION TEST FOR LEARNING OUTCOMES IN THE COGNITIVE DOMAIN

\begin{tabular}{|c|c|c|c|c|c|c|}
\hline & \multirow{2}{*}{ Model } & \multicolumn{2}{|c|}{$\begin{array}{l}\text { Unstandardized } \\
\text { Coefficients }\end{array}$} & \multirow{2}{*}{$\begin{array}{c}\begin{array}{c}\text { Standardized } \\
\text { Coefficients }\end{array} \\
\text { Beta }\end{array}$} & \multirow{2}{*}{$\mathbf{t}$} & \multirow{2}{*}{ Sig. } \\
\hline & & B & $\begin{array}{c}\text { Std. } \\
\text { Error }\end{array}$ & & & \\
\hline \multirow[t]{2}{*}{1} & (Constant) & 72.233 & 2.651 & & 27.248 & 0.000 \\
\hline & LCT Score & 0.230 & 0.054 & 0.593 & 4.296 & 0.000 \\
\hline
\end{tabular}

TABLE XI

LCT LINEAR REGRESSION TEST FOR LEARNING OUTCOMES IN THE AFFECTIVE DOMAIN

\begin{tabular}{|c|c|c|c|c|c|c|}
\hline & \multirow{2}{*}{ Model } & \multicolumn{2}{|c|}{$\begin{array}{c}\text { Unstandardized } \\
\text { Coefficients }\end{array}$} & \multirow{2}{*}{$\begin{array}{c}\begin{array}{c}\text { Standardized } \\
\text { Coefficients }\end{array} \\
\text { Beta }\end{array}$} & \multirow{2}{*}{$\mathbf{t}$} & \multirow{2}{*}{ Sig. } \\
\hline & & B & $\begin{array}{l}\text { Std. } \\
\text { Error }\end{array}$ & & & \\
\hline \multirow[t]{2}{*}{1} & (Constant) & 86.884 & 0.634 & & 137.121 & 0.000 \\
\hline & LCT Score & -0.027 & 0.013 & -.0343 & -2.128 & 0.041 \\
\hline
\end{tabular}

Based on Table XI, the linear regression equation is as follows: $\mathrm{R}=86,884-0,027 \mathrm{X}$. If student LCT does not change/constant, the affective domain learning outcomes are worth 86,884 . The significance shows $0.041<0.05$ so that it can be concluded that there is a significant positive effect of LCT on learning outcomes in affective domains.

Furthermore, how is the effect of LCT on psychomotor domain learning outcomes? The effect of LCT on psychomotor domain learning outcomes was analyzed through statistical software as shown in Table XII.

TABLE XII

LCT LINEAR REGRESSION TEST FOR LEARNING OUTCOMES IN THE PSYCHOMOTOR DOMAIN

\begin{tabular}{llcccrc}
\hline & & \multicolumn{2}{c}{$\begin{array}{c}\text { Unstandardized } \\
\text { Coefficients }\end{array}$} & $\begin{array}{c}\text { Standardized } \\
\text { Coefficients }\end{array}$ & & \multirow{2}{*}{ Sig. } \\
\cline { 3 - 5 } & & B & $\begin{array}{c}\text { Std. } \\
\text { Error }\end{array}$ & Beta & & \\
\hline 1 & (Constant) & 75.977 & 1.353 & & 56.151 & 0.000 \\
& LCT Score & 0.078 & 0.027 & 0.438 & 2.841 & 0.008 \\
\hline
\end{tabular}

Based on Table XII, the linear regression equation is as follows: $\mathrm{R}=75,977+0,078 \mathrm{X}$. If the student LCT does not change/constant, the psychomotor domain learning outcomes are worth 75,977 . The significance shows $0.008<0.01$ so it can be concluded that there is an effect of LCT on psychomotor domain learning outcomes, positively and very significantly.

\section{B. Discussions}

Based on the results of the research as described above, the further discussion needs to be done, to compare the findings obtained with relevant theories and research.

The study found that there was a significant positive effect of LCT on student XI BDT learning outcomes. The results of this study are in line with the findings of Leikin (2009) through research entitled "Exploring mathematical creativity using multiple solution tasks", which concluded that using test questions type of multiple solution task 
showed that: (1) the creativity of gifted students was higher than expert students not gifted; and (2) expert student creativity is higher than the creativity of high achievers.

The findings of this study are in line with the results of the Nami \& Maral (2014) study titled "The Relationship between Creativity and Academic Achievement", which concluded that the sample size of 72 subjects used to collect questionnaire data and Torrens creativity resulted in a significant positive relationship. Likewise, the results of this study are in line with the findings of Kuo, Chen, and Hwang 2014) through a study entitled "A creative approach to enhancing the web-based problem-solving performance of university students", who found that creative thinking strategy approaches can improve student performance in solving web-based problems, compared to conventional approaches.

The web is a learning media that helps students in learning, as well as other media such as e-learning, modules, and others. The learning media will provide benefits in the learning process including facilitating interaction between teachers and students so that learning activities will be more effective and efficient (Muslim et al., 2018). The use of elearning will also be very helpful in the learning process. Soeparno \& Muslim (2018) conducted a study entitled "Effectiveness of E-Learning for Vocational High School Building Engineering Program Students " found that elearning as a learning media in building techniques has advantages, because materials and assignments can be accessed easily, when and anywhere, and efficient in communication and discussion between students and teachers.

More than that, vocational learning in the XXI century must be designed to provide an impressive learning experience (Sudira, 2018: 262), so that students: (1) know what to do; (2) can do; ) aware, why should be done. Such learning experience, will: (1) support the acquisition of practical life skills; (2) make students more aware of the context of their work; (3) students will be better able to capture opportunities; and (4) provide a foundation for students as prospective entrepreneurs to establish social/commercial activities (Usman \& Tasmin, 2015). Such learning experiences are important for students who will live later on. Because according to Sudira (2018: 200), that century workers XXI, is not only productive enough, but they must be able to service quickly, meticulously, smartly, and satisfy customers. Therefore Boahin and Hofman (2013) suggest that competency-based industry training (CBT) should be in the education system and vocational training, a priority in many countries. Competency-based industry training (CBT) will be more effective if it is equipped with media or multimedia.

Some other research results that are in line with the findings of this study are Turkmen \& Sertkahya (2015), Gajda (2016), and Ridong, Xiaohui, and Chichjen (2017). Turkmen \& Sertkahya (2015) through research entitled "Creative Thinking Skills Analyzes of Vocational High School Students", concluded that there was a positive relationship, but only limited ability to think creatively with academic success (cognitive learning outcomes) of Vocational High School students. The results of the Gajda study (2016) with the title "The relationship between school achievement and different educational stages" support the results of this study, that there is a positive but weak relationship between creativity and middle-class student achievement. Likewise the findings of Ridong, Xiaohui, and Chichjen (2017), which states that creative problem solving based on indicators of creative thinking, can improve students' ability to solve problems and improve positive attitudes/affective learning outcomes of students, also supports the results of this study.

\section{CONCLUSIONS AND SUGGESTIONS}

\section{A. Conclusions}

Based on the description of the results of the research and discussion conclusions can be drawn as follows: 1 . There are as many as 4 students $(5.56 \%)$ included in the category of LCT 4 (very creative), there are 12 students $(33.33 \%)$ who fall into the category of LCT 3 (creative), there are 11 students $(30.56 \%$ ) included in the category 2 LCT (quite creative), there were no students included in the category of LCT 1 (less creative), and there were as many as 11 students $(30.56 \%)$ included in the category of LCT 0 (not creative).2. There is a significant positive effect between the level of creative thinking on cognitive and psychomotor realm learning outcomes in class XI BDT of SMK Negeri 1 Nganjuk, and there is a very significant positive influence between the level of creative thinking (LCT) on affective domain learning outcomes in class XI BDT SMK Negeri 1 Nganjuk.

\section{B. Suggestions}

Suggestions are described based on the conclusions that are intended as input for better research results. Suggestions in research are described as follows:

1) Teachers should apply learning models that are following LCT students and provide learning from experiences that often occur in the field by not limiting the scope and sources of learning used by students and getting used to providing problems that have many ways of solving so that students' creativity can improve.

2) Students who have LCT 0 do not mean they are unable to solve problems creatively, but sometimes students are less careful at the end of the completion process so that an LCT instrument is needed that tolerates judgment when students work with the right method.

3) Elaboration in problem-solving needs to be added to the LCT component (fluency, flexibility, and novelty) in subsequent studies so that the results of student LCT measurements can be analyzed in more detail.

\section{REFERENCES}

Anonymous. (2019, May 20). Profil Program Keahlian Desain Pemodelan dan Informasi Bangunan. Retrieved from https://smkn1nganjuk. sch.id/teknik-gambar-bangunan. 
Artmanda W, \& Frista. (2015) Kamus besar lengkap bahasa Indonesia. Jombang: Lintas Media.

Bingolbali, E. (2011). Multiple Solutions to Problems in Teaching: Do Teachers Really Value Them? Australian Journal of Teacher Education. 36 (1),1831.

Career Center Maine Department of Labor. (2004). Today's work competence in maine. (Online), http://w ww.maine.gov/labor/lmis/pdf/Essential

WorkCompetencies.pdf.

Colangelo, N., \& Davis, G. (2011). The reference in gifted education. Translated by Saleh Abo-Gado \& Mahmoud Abo-Gado, Riyadh: Obeikan Publishing.

Departemen Pendidikan Nasional. (2006). Kurikulum Tingkat Satuan Pendidikan. Jakarta: Depdiknas.

Gajda, A. (2016). The relationship between school achievement and creativity at diffrerent educational stages. Thingking Skill and Creativity. 19(1),246259 doi.org/10.1016/ j.tsc. 2015.12.004

Hidayatulloh, \& Suparji. (2015). Analisis tingkat Berpikir Kreatif Siswa kelas X TGB-1 pada Materi Pengukuran Luas Peta Situasi Melalui Pemecahan Masalah tipe Multiple Solution Task di SMK Negeri 1 Nganjuk. Jurnal Kajian Pendidikan Teknik Bangunan, 1(1), 122-128

Howard, J. (2002). A dual-state model of creative cognition for supporting strategies that foster creativity in the classroom. .International Journal of Technology and Design Education.12(1), 215-226.

Kuo, F., Chen, N., \& Hwang, G. (2014). A creative thingking approach to enhancing the web based problem solving performance of university students. Computers and Education.72(1),220230.doi.org/10.1016/ j.compedu.2013.11.005

Leikin, R. (2009). Exploring mathematical creativity using multiple solution tasks. Creativity in and the education of gifted students. 9(23), 129-145.

Muslim, S., et al. (2018). Development of Human Mechanic Interface Auotonics S070 Trainer for Electric Motor Installation Learning. Advances in Social Science, Education and Humanities Research (ASSEHR), volume 201 International Conference on Indonesian Technical Vocational Educa-tion and Association (APTEKINDO). Copyright (C) 2018, the Authors. Published by Atlantis Press. This is an open access article under the $\mathrm{CC}$ BY-NC license (http://creativecommons.org/ licenses/ by-nc/4.0/).

Nami, Y., \& Maral, A. (2014). The Relationship between Creativity and Academic Achievement. Procedia Social and behavior scinces.144(4),36-39. doi.org/10. 1016/j.sbspro.2013.12.652

Nur'aeni. (2008). Ada apa dengan Kreativitas. Cakrawala pendidikan. 7(3), 37-46.

Ridong, H., Xiaohui, S., \& Chichjen, S. (2017). A Study on the Application of Creative Problem Solving Teaching to Statistics Teaching. EURASIA Journal of Mathe-matics Science and Technology Education. 13(7),3139-3149.doi:10.12973/eurasia. 2017.00708a

Silver, E. A. (1997). Fostering creativity through instruction rich in problem solving and problem posing. $Z D M$ University of Pittsburgh. 3(12), 75-80,

Siswono, T.Y.E. (2008). Model pembelajaran matematika berbasis pengajuan dan pemecahan masalah untuk meningkatkan kemampuan berpikir kreatif. Surabaya: Unesa University Press.

Soeparno, \& Muslim, S. (2018). Effectiveness of E-Learning for Students Vocational High School Building Engineering Program. IOP Conf. Series: Materials Science and Engineering 336 (2018) 012039doi:10. 1088/1757-899X/336/1/012039.

Sudira, P. (2018). Metodologi pembelajaran vokasional abad XXI: Inovasi, teori dan praktis. Yogyakarta: UNY PressUndang-undang No.3 Tahun 2014 tentang perindustrian.

Thomas, M. (2005). Creative thinking and talking in residential care. therapeutic community.The International Journal for Therapeutic and Supportive Organizations. 26(1), 115-125.

Trilling, B., \& Fadel, C. (2009). 21st century skills: Learning for life in our times. San Fransisco: Wiley

Turkmen, H., \& Sertkahya, M. (2015). Creative Thinking Skills Analyzes of Vocational High School Students. Journal of Education and Intructional Studies. 5(1).74-84.

Usman, A.S. dan Tasmin, R (2015). Entrepreneurial Skills Development Strategies through the Mandatory Students' Industrial Work Experience Scheme in Nigeria. https://doi. org/10.1016/ j.sbspro .2015. $\underline{08.148 .}$ 